\title{
Diphenhydramine Compact-Cell Sensor
}

\author{
Mohsen M. Zareh ${ }^{1,2 *}$, Mohammed I. ALahmdi' ${ }^{1}$, Ali A. Keshk ${ }^{1}$ \\ ${ }^{1}$ Department of Chemistry, Faculty of Science, Tabuk University, Tabuk, Saudi Arabia \\ ${ }^{2}$ Department of Chemistry, Faculty of Science, Zagazig University, Zagazig, Egypt \\ Email: *mzareh@ut.edu.sa, mohsenzareh@hotmail.com
}

Received 6 January 2016; accepted 28 March 2016; published 31 March 2016

Copyright (C) 2016 by authors and Scientific Research Publishing Inc.

This work is licensed under the Creative Commons Attribution International License (CC BY).

http://creativecommons.org/licenses/by/4.0/

cc) (i) Open Access

\section{Abstract}

The construction and performance characteristics of a novel (diphenhydramine) DPH CC-sensor based on DZCE were reported in this work. The CC-membrane was prepared by incorporating of (diazacrown ether) DZCE and/or (tetraflorophenyl borate) TFPB into a plasticized poly(vinyl chloride) membrane. The CC-sensor revealed a Nernstian behavior over a DPH-concentration range $\left(9.1 \times 10^{-3}-6.3 \times 10^{-7} \mathrm{~mol} \cdot \mathrm{L}^{-1}\right)$, and relatively low detection limit $\left(1 \times 10^{-7} \mathrm{~mol} \cdot \mathrm{L}^{-1}\right)$. The potentiometric response was independent on the $\mathrm{pH}$ of the solution in the range of $7-10$. The DPH-CC showed a very short response time $(<5 \mathrm{~s})$. It showed good selectivity towards different cations and pharmaceutical compounds. The relative selectivity coefficient was applied for evaluation of the selectivity properties of the DPH-CC. The DPH-CC was used successfully for determination of DPH in its samples. The found recovery range was $95 \%-98.5 \%$, and the standard deviation value ranged between 0.13 - 0.42. The DPH-CC facilitates the analysis of DPH directly without pretreatment and it can be built-in as a detector in chromatographic apparatus. It can be used as a tool for on-line monitoring of the drug levels.

\section{Keywords}

Compact Cell, Diphenhydramine Determination, Drug Sensor

\section{Introduction}

Diphenhydramine $\left(\mathrm{C}_{17} \mathrm{H}_{21} \mathrm{NO}\right)$ is 2-(diphenylmethoxy)-N,N-dimethylethanamine. It has an antihistamine possessing anticholinergic, antitussive, antiemetic, and sedative properties that is mainly used to treat allergies. It is also used in the management of drug-induced Parkinsonism and other extrapyramidal symptoms. The drug has a strong hypnotic effect and is FDA-approved as a nonprescription sleep aid, especially in the form of diphenhydramine citrate. The drug was first synthesized by George Rieveschl and first made publicly available through

${ }^{*}$ Corresponding author. 
prescription in 1946 [1].

Several methods were used for analysis of diphenhydramine. Eman et al. [2] applied a potentiometric determination of antihistaminic diphenhydramine hydrochloride in pharmaceutical preparations and biological fluids using screen-printed electrode. It had a linear range $10^{-2}-10^{-6} \mathrm{M}$ and slope of 55.2 and $54.7 \mathrm{mV} /$ decade. The detection limit was $9.8 \times 10^{-7} \mathrm{M}$ in pH range 3 - 8. Dönmez et al. [3] applied HPLC-method for analysis of DPH in presence of potassium guaiacolsulfonate, guaifenesin and carbetapentane citrate. Wang et al. [4] developed and validated a liquid chromatography/tandem mass spectrometry analysis of DPH, and d-amphetamine. They used mobile phase of methanol-water-formic acid at rate of $0.2 \mathrm{ml} / \mathrm{min}$. Ali et al. [5] applied a hydrophilic interaction liquid chromatographic (HILIC) procedure for the simultaneous determination of pseudoephedrine hydrochloride (PSH), diphenhydramine hydrochloride (DPH) and dextromethorphan hydrobromide (DXH) in cough-cold formulations. The method showed a linear range for DPH $62.5-250 \mu \mathrm{g} / \mathrm{ml}$ and recovery $100.1 \%$. Dong et al. [6] applied a non-aqueous capillary zone-electrophoresis for separation and determination of pseudoephedrine, dextromethorphan, diphenhydramine (DPH) and chlorpheniramine. The used buffer was composed of ammonium acetate, acetonitrile in methanol. Gomez et al. [7] used a capillary zone-electrophoresis method for the determination of codeine, diphenhydramine, ephedrine and noscapine. They used tetraborate buffer at $\mathrm{pH}$ 8.5. UV detection was at 205 and $250 \mathrm{~nm}$ for a range of $0.42-1.33 \mu \mathrm{g} / \mathrm{ml}$. Barbas et al. [8] used isocratic highperformance liquid chromatography for determination of caffeine, 8-chlorotheophylline and diphenhydramine (DPH) with UV detection at $229 \mathrm{~nm}$. The mobile phase was composed of acetonitrile and buffer (phosphate: trimethylamine) $\mathrm{pH}$ 2.8. Okamoto et al. [9] separated and determined DPH and other ingredients by hydrophobic interaction electrokinetic chromatography. The separation solution was composed of tetradecyl ammonium salt and ammonium chloride. Recovery range was 98\% - 100\%. Shoukry et al. [10] introduced a PVC membrane electrode for determination of diphenhydramine. The membrane was based on tetraphenyl borate as charged ionophore.

In this work, original compact cell for diphenhydramine "DPH-CC" was applied successfully for determination of the drug. There was no need to use separate reference and sensor electrode for analysis like old electrode methods [9] [10]. No need for large amounts of solvents like in chromatographic methods [8] [10]. Only one set sensor was used for analysis. The fabrication of the cell was based on previous explained procedures by Zareh [11]. It is composed of two compartments, one for the reference and the other was for DPH-sensor part. Many benefits of using such cell were found especially for built-in devices. It facilitates the direct analysis of the drug. The DPH-CC can be easily used as a detector for the drug analysis.

\section{Experimental}

\subsection{Reagents and Material}

Diphenhydramine hydrochloride $\left(\mathrm{C}_{17} \mathrm{H}_{21} \mathrm{NOHCl}\right) 291.855 \mathrm{~g} / \mathrm{mol}$ was purchased from (Sigma). Diaza-18-crown6 ether (DZCE) (previously prepared) [11] and tetra-kis-(trifloromethyl-phenyl) borate potassium salt (TFPB-K) (Aldrich) were the main ionophores for preparing the membranes. Figure 1 shows the structrure formule of these compounds. The plasticizers were either dodecyl phthalate (DDP) (Fluka) or nitrophenyloctyl ether (NOPE) (Fluka). Polyvinylchloride (PVC) (Fluka) was the membrane matrix. The membrane components were dissolved in tetrahydrofuran (THF) (Fluka). A 0.1 M standard stock solution of DPH (Sigma-Aldrich) was prepared. Less concentrated solutions were obtained by careful dilution of the standard stock solution. Several pharmaceutical formulations were purchased from local market for analysis of real samples using the proposed DPH- Compact Cell. These formulations were Exylin Pediatric Syrup, (Spimaco, Saudi Arabia); Amydramine Expectorant Syrup Sugar Free, (Gulf Pharmaceutical Industries, Julphar, United Arab Emirates); Koffex Syrup for Adult, (Xellia Pharmaceutical Aps, Denmark); Ezipect Syrup, (Tabuk Pharmaceutical Manufacturing Co, Saudi Arabia). Double distilled water was used throughout.

\subsection{Equipment}

The potentiometric/pH-measurements were carried out at $25^{\circ} \mathrm{C} \pm 1{ }^{\circ} \mathrm{C}$ on a digital research pH-meter (model 5986) Cole-Parmar (sensitivity $\pm 0.1 \mathrm{mV}$ ) coupled with a channel selector of the same make. $\mathrm{pH}$-meter (Jenway, UK), hotplate \& stirrer (LabTech Co. Ltd, Indonesia). 
<smiles>CN(C)CCOC(c1ccccc1)c1ccccc1</smiles>

(a)<smiles>CCOC(=O)CN1CCOCCOCCN(C(=O)OCC)CCOCCOCC1</smiles>

$\mathrm{N}, \mathrm{N}$-bisethoxycarbonyl-1,10-diaza4,7,13,16-tetraoxacyclo-octadecane (DZCE)

(b)

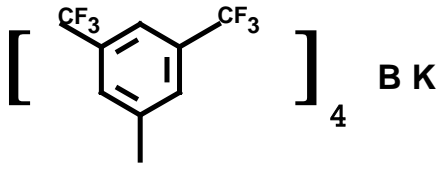

Potassium tetrakis[3,5-bis(trifloromethyl) -phenyl] borate (KTFPB)

(c)

Figure 1. Structure formula of: (a) diphenhydramine (DPH), (b) N,N-bis-ethoxycarbonyl-1, 10-diaza-4,7,13,16-tetraoxacyclo-octadecane (DZCE), (c) potassium tetra kis-(trifloromethylphenyl) borate (TFPB).

\subsection{Compact Cell Preparation}

The measurement was carried using a compact-cell [12], which was assembled using Teflon rod (length $=10 \mathrm{~cm}$, diameter $=12 \mathrm{~mm}$ ). It is composed of two separate compartments. The first compartment contains DPH ISE, while the second compartment contains the reference Ag/AgCl electrode. The PVC-membrane was fixed to the end of the first compartment. The side end of the second compartment was fitted with a porous membrane. Figure 2 shows the composition of the DPH-compact cell.

Three membrane compositions (I-III) were tried 1\% w/w ionophore (either DZCE or TFPB); 33\% w/w PVC and $66 \% \mathrm{w} / \mathrm{w}$ solvent mediators (NOPE) or (DDP). Table 1 shows the three compositions. These components were dissolved in THF and poured into glass rings of $4 \mathrm{~cm}$ i.d. resting on a glass plate. The mixture was left overnight for evaporation, and then the resulting membrane was cut into discs of $7 \mathrm{~mm}$ i.d. The obtained discs were fixed to the end of ISE-compartment of a CC made from Teflon. The electrode-compartment was filled with an aqueous inner filling cell electrolyte $(0.01 \mathrm{M} \mathrm{DPH}+0.01 \mathrm{M} \mathrm{KCl})$ (IF). After adjustments of CompactCell "CC", it was soaked for $24 \mathrm{~h}$ into $1 \times 10^{-2} \mathrm{M}$ solution of DPH.

\subsection{Potentiometric Measurements}

Fifty milliliter aliquots of DPH solution $\left(10^{-7}-10^{-2} \mathrm{M}\right)$ were transferred to $100 \mathrm{~mL}$ beakers. The DPH-compact cell was dipped into the solution. The cell potential was recorded corresponding to each DPH concentration. A calibration graph was constructed for the cell potential versus $\log (\mathrm{DPH})$. The following cell assembly was applied:

Ag-AgCl/Inner filling soln./membrane//sample solution//reference inner filling soln./Ag-AgCl

The $\mathrm{pH}$-measurements were carried out by immersing the proposed DPH-CC plus glass electrode into $50 \mathrm{ml}$ DPH-solutions of concentrations $10^{-2}-10^{-4} \mathrm{M} \mathrm{DPH}$. The potential values of the proposed cell were recorded against $\mathrm{pH}$ values. The potentiometric selectivity coefficient $\left(K_{\mathrm{DPH}, \mathrm{X}^{\mathrm{Z}}}^{\mathrm{Pot}}\right)$ values for different common cations were determined by the separate solution method [13] $\left(10^{-3} \mathrm{M}\right.$ solutions for both DPH and interferent). 


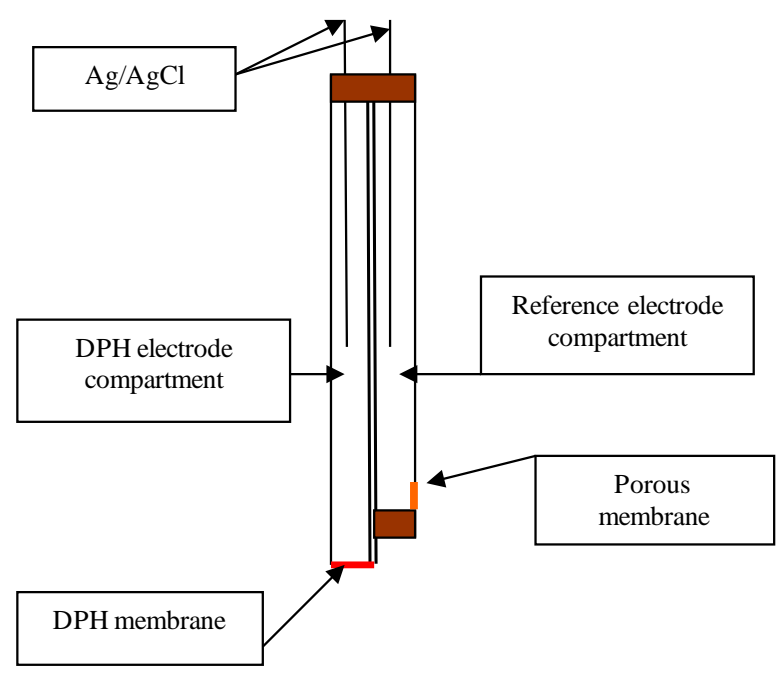

Figure 2. Composition of DPH- compact cell.

Table 1. Membrane composition of DPH-CC types I, II and III.

\begin{tabular}{cccccc}
\hline Composition, w/w \% & PVC, $\mathrm{mg}$ & DZCE, $\mathrm{mg}$ & TFPB, $\mathrm{mg}$ & DDP, $\mathrm{mg}$ & NPOE, mg \\
\hline I-membrane & 33.8 & 0 & 1.2 & 0 & 60 \\
II-membrane & 31.5 & 2 & 1.6 & 67 & 0 \\
III-membrane & 30.5 & 1.15 & 0 & 67 & 0 \\
\hline
\end{tabular}

\subsection{Determination of DPH in Its Samples Using DPH-CC}

Different DPH-containing samples were prepared. Either the direct potentiometry or the standard addition method was used for analyzing these samples by using the proposed DPH-CC. In direct potentiometric method, 50 $\mathrm{ml}$ aliquots of the chosen samples: Exylin Pediatris (syrup), Amydramine Expectorant (syrup), Koffex (sytrup) or Ezipect (syrup), were transferred to the potentiometric cell. Then, the DPH-CC was immersed into the syrup. The potential values were recorded and compared to a previously prepared calibration graph.

For the standard addition method, $50 \mathrm{ml}$ aliquouts were transferred to the potentiometric cell. Then, $5 \mathrm{ml}$ of each drug sample was added. Finally, the potential values were recoded and compared to the previously prepared calibration graphs. The concentration of each sample was calculated after deduction of the standard concentration.

\section{Results and Discussion}

\subsection{Effect of Membrane Composition on CC-Performance}

Three DPH-CC compositions were tried. The first type was based on TFPB as a charged ionophore (type-I). Other types (II and III) were based on neutral ionphore DZCE (2 and $1.15 \mathrm{mg}$ ) in presence of TFPB (2 mg). The slope of the calibration graphs for the three types of cells was (56.86 mV/decade), which is close to Nernstian value (59.8 $\mathrm{mV} /$ decade). The linear range of the three types of DPH-CC was $\left(9.1 \times 10^{-3}-6.3 \times 10^{-7} \mathrm{M}\right)$. The detection limit for all types was $10^{-7} \mathrm{M}$. Figure 3 shows the obtained results after one days soaking of DPH-CC in $10^{-2} \mathrm{M}$ DPH solution.

The mechanistic equation that represents the exchange reaction at the membrane-solution interface for DPHCC type-I (contains only DZCE) is written as below:

$$
\begin{aligned}
& (\mathrm{DPH})^{+}+[\mathrm{DZCE}]=[(\mathrm{DZCE}-\mathrm{DPH})]^{+} \\
& K_{e q}=[\mathrm{DZCE}-\mathrm{DPH}]^{+} /\left[\mathrm{DPH}^{+}\right][\mathrm{DZCE}]
\end{aligned}
$$




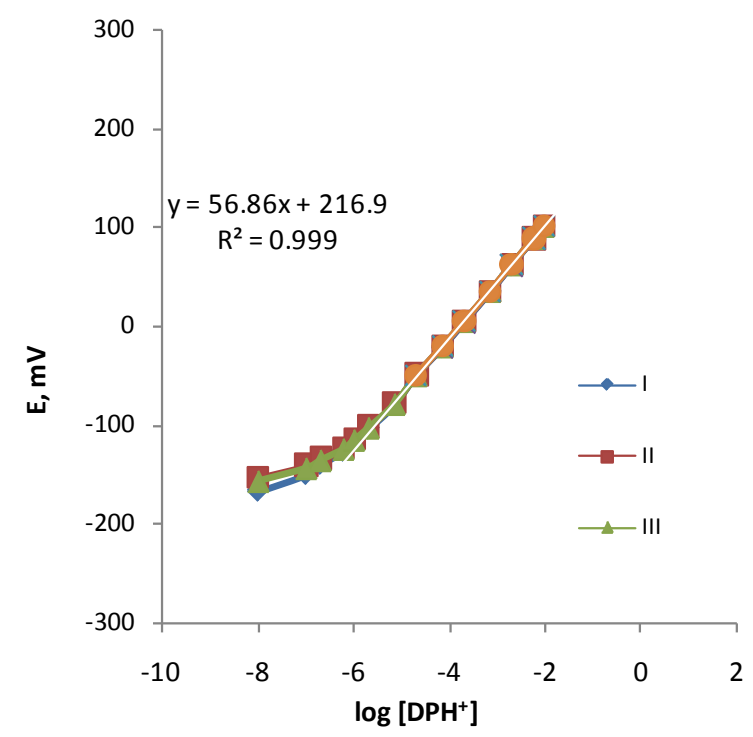

Figure 3. Calibration graphs of DPH-CC of different compositions contains I) TFPB, II) TFPB + DZCE, III) TFPB + DZCE.

In case of DPH-CC types-II and III (contains DZCE/K-TFPB), the following equilibrium is expected :

$$
\begin{aligned}
& {[\mathrm{TFPB}]^{-} \mathrm{K}^{+}+\mathrm{DZCE}=\left[(\mathrm{DZCE}-\mathrm{K})^{+} \mathrm{TFPB}^{-}\right]} \\
& {\left[(\mathrm{DZCE}-\mathrm{K})^{+} \mathrm{TFPB}^{-}\right]+(\mathrm{DPH})^{+}=\left[(\mathrm{DZCE}-\mathrm{DPH})^{+} \mathrm{TFPB}^{-}\right]+\mathrm{K}^{+}} \\
& K_{\text {eq }}=\left[(\mathrm{DZCE}-\mathrm{DPH})^{+} \mathrm{TFPB}^{-}\right]\left[\mathrm{K}^{+}\right] /\left[(\mathrm{DZCE}-\mathrm{K})^{+} \mathrm{TFPB}^{-}\right]\left[(\mathrm{DPH})^{+}\right]
\end{aligned}
$$

The dynamic response of the three cells was tested by measuring the potential value against time. The measurements were carried for different concentrations in the range of $10^{-2}$ to $10^{-7} \mathrm{M}$. Figure 4, shows the obtained results. From the figure, the response time of the DPH-CC was less than 5 seconds. This means that the cell shows fast response for the drug measurement.

\section{2. pH-Effect}

The potential changes versus different $\mathrm{pH}$-values for the three kinds of the membranes were studied. It was tested for $9.1 \times 10^{-3}-7 \times 10^{-5} \mathrm{M}$ DPH solutions for the three types (I,II,III) of DPH-CC. The measurement aimed to find the optimum working $\mathrm{pH}$-range for each type. The optimum $\mathrm{pH}$-range is defined as the $\mathrm{pH}$-range where the potential value of the cell does not change whatever the $\mathrm{pH}$ is changed. Wide $\mathrm{pH}$ range was found for three types. The $\mathrm{pH}$ range was 3.57 - 8.4. The break in acidic part was due to the interference from $\mathrm{H}^{+}$. After $\mathrm{pH}$ 8.4 the sudden change in potential was due to the formation of free base of DPH. Figure 5 showed the changes in $\mathrm{pH}$-potential changes for different concentrations when DPH-CC was used. It was found that the optimum pH-range showed little changes for $9.1 \times 10^{-3}$ than for lower concentrations $7 \times 10^{-4}$ and $7 \times 10^{-5} \mathrm{M} \mathrm{DPH}$. It was $3.17-7.85$ for $9.1 \times 10^{-3}$, while it was $3.6-8.72$, 3.6 - 8.4 for lower concentrations $7 \times 10^{-4}$ and $7 \times 10^{-5} \mathrm{M}$ $\mathrm{DPH}$. This little change is attributed to the interaction with the hydroxide ion forming the free DPH-base. The three DPH-CC types I, II and III showed similar potential-pH plateau when $7 \times 10^{-5} \mathrm{M} \mathrm{DPH}$ solution was tested (Figure 6).

\subsection{Selectivity Properties}

The selectivity coefficient ( $K_{i, j}^{\text {pot }}$ ) was determined for evaluating selectivity properties of the three types of DPH-electrodes I, II, III. The values were calculated by the SSM according to IUPAC [13]: 


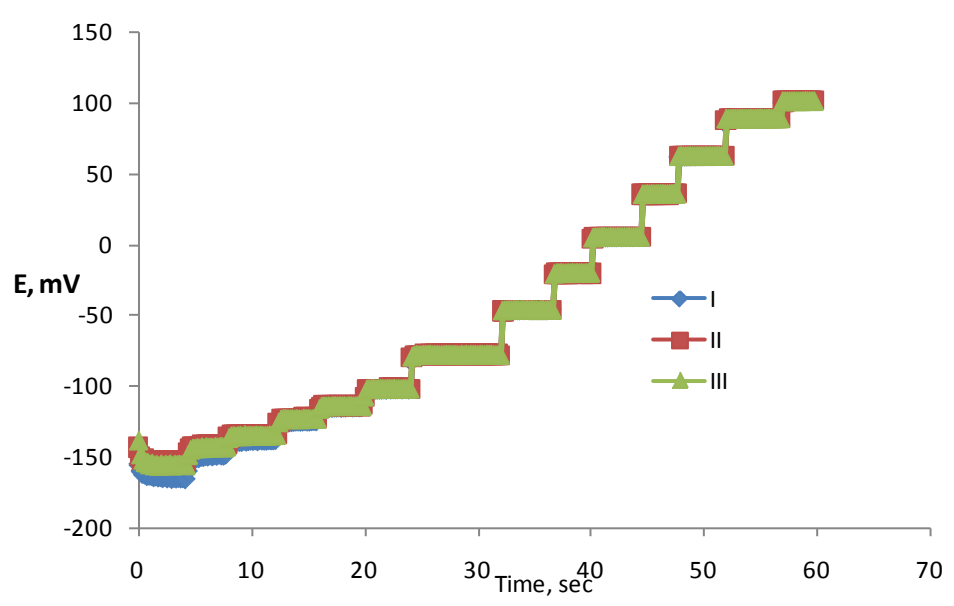

Figure 4. Dynamic response of the three types of DPH-compact cell.

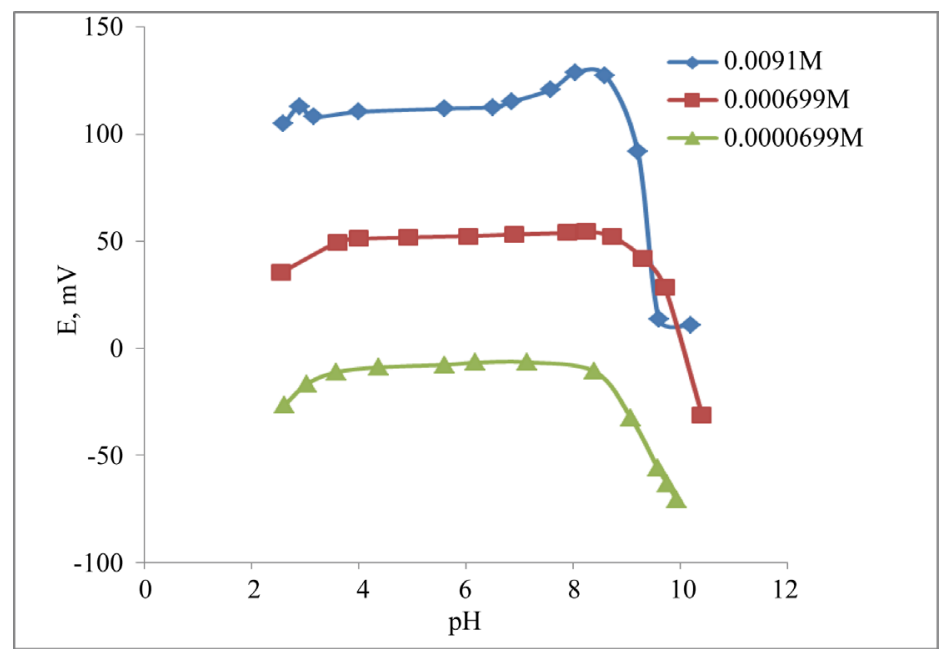

Figure 5. pH-effect on the potential of DPH- CC with membranes type-II when measuring different concentrations of DPH a) $9.1 \times 10^{-3} \mathrm{M}$, b) $7.0 \times$ $10^{-4} \mathrm{M}$, and c) $7.0 \times 10^{-5} \mathrm{M}$ solution.

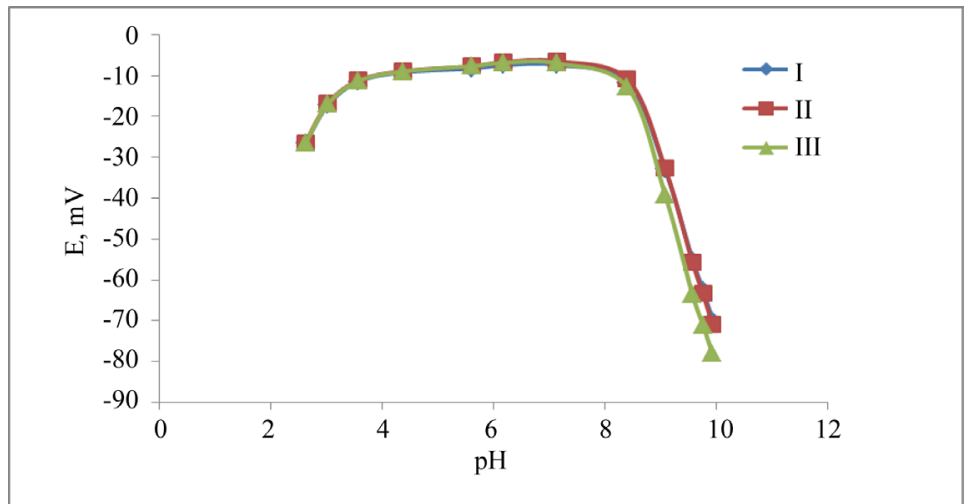

Figure 6. pH-effect on the potential of DPH- CC with membranes types-I, II, and III for DPH $7 \times 10^{-5} \mathrm{M}$ solution.

$$
\log K_{\mathrm{DPH}^{+}, j^{z+}}^{\mathrm{pot}}=\left(E_{j}-E_{\mathrm{DPH}^{+}}\right) / S+\left[1-\left(Z_{\mathrm{DPH}^{+}} / Z_{j^{z+}}\right)\right] \log a_{\mathrm{DPH}^{+}}
$$


It can be recorded that the $K_{\mathrm{DPH}, j^{Z+}}^{\mathrm{Pot}}$-values for the tested common inorganic cations was of the order of $10^{-5}$ for the three electrode types. These values reveals a perfect selectivity of the three DPH-CC types towards the common cations (namely $\mathrm{K}^{+}, \mathrm{Na}^{+}, \mathrm{Li}^{+}, \mathrm{Ca}^{2+}, \mathrm{Mg}^{2+}, \mathrm{NH}_{4}^{+}$and $\mathrm{Ba}^{2+}$ ). Here, it can be recommended that any of the studied electrodes are ready for the DPH-measurement in presence of these cations. The $K_{\mathrm{DPH}, j^{z^{+}}}^{\mathrm{Pot}}-$ values towards the tested pharmaceutical compounds showed higher $K_{\mathrm{DPH}, j^{2+}}^{\mathrm{Pot}}$-for type-I rather than types-II and III. It was found that the $K_{\mathrm{DPH}, j^{2+}}^{\text {Pot }}$-values for type-I electrode were of the order of $10^{-2}$, while for types II and III, they are of order of $10^{-3}$. This shows better selectivity for DPH-CC types II and III with respect to the tested pharmaceutical compounds than for type-I. Only quinine showed the highest value of the $K_{\mathrm{DPH}, j^{Z_{+}}}^{\mathrm{Pot}}$ values, which reflects the lower selectivity towards this compound. Table 2 shows the obtained $K_{\mathrm{DPH}, j^{\mathrm{Z}}}^{\mathrm{Pot}}$ values for the electrode types.

The relative selectivity coefficient $K_{\text {rel }}$ was defined by Zareh [14] as a new parameter for evaluating the selectivity of the tested electrodes. The $K_{\text {rel (x=I,II,III) }}$ for the three electrode types for each tested interferent were calculated. Then, the $K_{\mathrm{av}(\mathrm{x}=\mathrm{IIII}, \mathrm{III})}$ for each type were calculated according to equations:

$$
\begin{aligned}
& \left(K_{\text {rel-I:III }}\right)_{a v}=\left[\sum_{1 \rightarrow n}\left(K_{\text {rel }}\right)_{\mathrm{I}: \mathrm{III}-n}\right] / n \\
& \left(K_{\text {rel-I:III }}\right)_{\mathrm{av}}=\left[\sum_{1 \rightarrow n}\left(K_{\text {rel }}\right)_{\mathrm{I}: \text { III- }-}\right] / n \\
& \left(K_{\text {rel-IIII }}\right)_{\text {av }}=\left[\sum_{1 \rightarrow n}\left(K_{\text {rel }}\right)_{\text {III-I- } n}\right] / n \\
& \left(K_{\text {rel-IIIIII }}\right)_{\mathrm{av}}=\left[\sum_{1 \rightarrow n}\left(K_{\text {rel }}\right)_{\text {II:III-n }}\right] / n \\
& \left(K_{\text {rel-IIIII }}\right)_{\text {av }}=\left[\sum_{1 \rightarrow n}\left(K_{\text {rel }}\right)_{\text {IIIII- }-n}\right] / n \\
& \left(K_{\text {rel-IIIIIII }}\right)_{\mathrm{av}}=\left[\sum_{1 \rightarrow n}\left(K_{\text {rel }}\right)_{\text {IIIIIII-n }}\right] / n
\end{aligned}
$$

\begin{tabular}{|c|c|c|c|}
\hline \multirow{2}{*}{ Interferent } & \multicolumn{3}{|c|}{$K_{\mathrm{DPH}, j^{2+}}^{\mathrm{Pot}^{2+}}$} \\
\hline & $\mathbf{I}$ & II & III \\
\hline Glycine & $6.8 \times 10^{-3}$ & $1.5 \times 10^{-3}$ & $2.2 \times 10^{-3}$ \\
\hline Arginin & $5.8 \times 10^{-3}$ & $1.0 \times 10^{-3}$ & $1.9 \times 10^{-3}$ \\
\hline Sodium glutmate & $1.4 \times 10^{-2}$ & $5.2 \times 10^{-3}$ & $6.3 \times 10^{-3}$ \\
\hline Ephedrine & $1.4 \times 10^{-2}$ & $5.2 \times 10^{-3}$ & $6.3 \times 10^{-3}$ \\
\hline Pilocarpine & $2.4 \times 10^{-2}$ & $2.9 \times 10^{-3}$ & $3.5 \times 10^{-3}$ \\
\hline Atropine & $2.6 \times 10^{-2}$ & $1.0 \times 10^{-2}$ & $1.2 \times 10^{-2}$ \\
\hline Quinine & $2.8 \times 10^{-1}$ & $2.2 \times 10^{-1}$ & $2.3 \times 10^{-1}$ \\
\hline Caffeine & $2.0 \times 10^{-3}$ & $4.3 \times 10^{-4}$ & $5.9 \times 10^{-4}$ \\
\hline KCL & $1.37 \times 10^{-4}$ & $1.68 \times 10^{-4}$ & $1.62 \times 10^{-4}$ \\
\hline $\mathrm{NaNO}_{3}$ & $4.99 \times 10^{-5}$ & $6.23 \times 10^{-5}$ & $6.33 \times 10^{-5}$ \\
\hline $\mathrm{LiNO}_{3}$ & $3.23 \times 10^{-5}$ & $4.21 \times 10^{-5}$ & $4.67 \times 10^{-5}$ \\
\hline $\mathrm{CaCl}_{2}$ & $2.96 \times 10^{-5}$ & $3.7 \times 10^{-5}$ & $2.51 \times 10^{-5}$ \\
\hline $\mathrm{Mg}\left(\mathrm{NO}_{3}\right)_{2}$ & $2.02 \times 10^{-5}$ & $2.66 \times 10^{-5}$ & $2.15 \times 10^{-5}$ \\
\hline $\mathrm{NH}_{4} \mathrm{NO}_{3}$ & $3.13 \times 10^{-5}$ & $4.64 \times 10^{-5}$ & $4.65 \times 10^{-5}$ \\
\hline $\mathrm{Ba}\left(\mathrm{NO}_{3}\right)_{2}$ & $1.83 \times 10^{-5}$ & $2.15 \times 10^{-5}$ & $1.59 \times 10^{-5}$ \\
\hline
\end{tabular}

where $(n)$ is the number of interferents under study.

Table 2. Selectivity coefficient values for DPH Compact Cell based on I) TFPB/NPOE, II) TFPB+DZCE/DDP, III) TFPB/ DDP membranes, when measuring $0.01 \mathrm{M}$ DPH/interferent solution. 
Finally, the $K_{\mathrm{tot}(\mathrm{x}=\mathrm{I}, \mathrm{II}}$ and III) was calculated for overall evaluation.

$$
\left(K_{\text {rel-X }}\right)_{\text {total }}=\left[\left(K_{\text {rel-X:1 } 1}\right)_{\mathrm{av}}+\left(K_{\text {rel-X:2: }}\right)_{\mathrm{av}}+\left(K_{\text {rel-X:3 } 3}\right)_{\mathrm{av}}+\left(K_{\text {rel-X:4 }}\right)_{\mathrm{av}}+\cdots+\left(K_{\text {rel-X:m } m}\right)_{\mathrm{av}}\right] /(m)
$$

where $X$, is the electrode under study; $(1,2,3,4, \cdots, m)$, refers to the number of electrodes to be compared with. It can be predicted that the smaller the $K$-value, the better the selectivity properties of an electrode. The $K_{\text {tot }(x=I I)}$ (0.86) is the least among the three tested electrodes. This indicates that the electrode type-II was the best among the tested electrode types. Table 3 showed the calculated values of $K_{\mathrm{rel}}, K_{\mathrm{av}}$, and $K_{\mathrm{tot}}$ for the three DPH-CC types.

\subsection{Analysis of Diphenhydramine Samples by Using DPH-CC}

By using DPH-CC the DPH assessment becomes easier without sample pretreatment. Since DPH-CC based on membrane type-II exhibited the best electrode performance, so it was applied for an actual analysis of DPH samples. Diphenhydramine formulations Exylin (7 mg/ml), Amydramine Expectorant (15 mg/ml), Koffex Syrup $(10 \mathrm{mg} / \mathrm{ml})$, and Ezipect Syrup $(2.5 \mathrm{mg} / \mathrm{ml})$ were assayed using the mentioned DPH-CC. The procedure was applied using both the direct potentiometric and the known addition techniques. The obtained results (Table 4), showed that the found percentage values were $98.5 \%$ - 97.8\% for direct potentiometry, and $95 \%-98.5 \%$ for known addition method. The Standard deviation (STD) values were $0.13-0.25$ for the direct potentiometry and 0.22 - 0.42 for the known addition method (4-determinations).

\section{Conclusions}

It can be concluded that diphenhydramine can be determined by using new generation of sensors based on using Compact Cell (CC).

Table 3. RelativeSelectivity coefficient values $\left(K_{\text {rel }}\right)$ for DPH-Compact Cell based on I) TFPB/NPOE, II) TFPB+DZCE/DDP, III) TFPB/DDP membranes, when measuring $0.01 \mathrm{M}$ DPH/interferent solution.

\begin{tabular}{|c|c|c|c|c|c|c|}
\hline \multirow{2}{*}{ Interferent } & \multicolumn{2}{|c|}{$K_{\text {rel-I }}$} & \multicolumn{2}{|c|}{$\boldsymbol{K}_{\text {rel-II }}$} & \multicolumn{2}{|c|}{$\boldsymbol{K}_{\text {rel-III }}$} \\
\hline & K-(I-II) & K-(I-III) & K-(II-I) & K-(II-III) & K-(III-I) & K-(III-II) \\
\hline Glycine & 0.81 & 0.84 & 1.23 & 1.04 & 1.19 & 0.96 \\
\hline Arginin & 0.80 & 0.79 & 1.25 & 0.98 & 1.27 & 1.02 \\
\hline Sodium glutmate & 0.77 & 0.69 & 1.30 & 0.90 & 1.45 & 1.11 \\
\hline Ephedrine & 0.80 & 1.18 & 1.25 & 1.47 & 0.85 & 0.68 \\
\hline Pilocarpine & 0.76 & 0.94 & 1.32 & 1.24 & 1.06 & 0.81 \\
\hline Atropine & 0.68 & 0.67 & 1.48 & 1.00 & 1.49 & 1.00 \\
\hline Quinine & 0.85 & 1.15 & 1.18 & 1.35 & 0.87 & 0.74 \\
\hline Caffeine & 4.35 & 3.09 & 0.23 & 0.71 & 0.32 & 1.41 \\
\hline KCL & 5.82 & 3.07 & 0.17 & 0.53 & 0.33 & 1.90 \\
\hline $\mathrm{NaNO}_{3}$ & 2.74 & 2.27 & 0.36 & 0.83 & 0.44 & 1.21 \\
\hline $\mathrm{LiNO}_{3}$ & 2.74 & 2.27 & 0.36 & 0.83 & 0.44 & 1.21 \\
\hline $\mathrm{CaCl}_{2}$ & 8.49 & 6.99 & 0.12 & 0.82 & 0.14 & 1.21 \\
\hline $\mathrm{Mg}\left(\mathrm{NO}_{3}\right)_{2}$ & 2.50 & 2.14 & 0.40 & 0.86 & 0.47 & 1.17 \\
\hline $\mathrm{NH}_{4} \mathrm{NO}_{3}$ & 1.29 & 1.21 & 0.77 & 0.94 & 0.83 & 1.07 \\
\hline $\mathrm{Ba}\left(\mathrm{NO}_{3}\right)_{2}$ & 4.74 & 3.43 & 0.21 & 0.72 & 0.29 & 1.38 \\
\hline $\mathbf{K}(\mathbf{a v}-\mathbf{x})^{*}$ & 2.54 & 2.05 & 0.78 & 0.95 & 0.76 & 1.13 \\
\hline $\mathbf{K}(\text { tot-x })^{*}$ & \multicolumn{2}{|c|}{2.30} & \multicolumn{2}{|c|}{0.86} & \multicolumn{2}{|c|}{0.94} \\
\hline
\end{tabular}


Table 4. Application of DPH-CC for determination of DPH in different samples.

\begin{tabular}{|c|c|c|c|c|c|c|}
\hline \multirow{2}{*}{ No. } & \multirow{2}{*}{ Diphenhydramine sample } & \multirow{2}{*}{$\begin{array}{l}\text { Taken } \\
\text { amount, } \\
\text { mg/ml }\end{array}$} & \multicolumn{2}{|c|}{ Direct potentiometry } & \multicolumn{2}{|c|}{ Known addition method } \\
\hline & & & $\begin{array}{l}\text { Percentage } \\
\text { found, \% }\end{array}$ & STD $^{*}$ & $\begin{array}{l}\text { Percentage } \\
\text { found, \% }\end{array}$ & STD $^{*}$ \\
\hline 1 & $\begin{array}{l}\text { Exylin Pediatric Syrup (Diphenhydramine } \\
\text { Hydrochloride, Menthol), Spimaco Saudi Arabia }\end{array}$ & 7 & 98.2 & 0.17 & 95.71 & 0.29 \\
\hline 2 & $\begin{array}{l}\text { Amydramine Expectorant Syrup Sugar Free, } \\
\text { (Diphenhydramine Hydrochloride, Ammonium, } \\
\text { Sodium Citrate, Menthol), Gulf Pharm. Ind. } \\
\text { (Julphar, United Arab Emirates }\end{array}$ & 15 & 98.5 & 0.25 & 98.5 & 0.22 \\
\hline 3 & $\begin{array}{l}\text { Koffex Syrup For Adult, (Diphenhydramine } \\
\text { Hydrochloride, Ammonium, Sodium Citrate) } \\
\text { Xellia Pharm. Aps, Denmark }\end{array}$ & 10 & 97.8 & 0.25 & 98 & 0.42 \\
\hline 4 & $\begin{array}{l}\text { Ezipect Syrup, (Diphenhydramine Hydrochloride), } \\
\text { Tabuk Pharmaceutical Manufacturing Co., Saudi } \\
\text { Arabia }\end{array}$ & 2.5 & 98 & 0.13 & 95 & 0.17 \\
\hline
\end{tabular}

*Standard deviation (4-determinations).

$>$ The cell is applied successfully for analyzing diphenhydramine down to $1 \times 10^{-7} \mathrm{M}$.

$>$ This type of cells can be elaborated for use to determine other drugs.

$>$ The benefits of using such cell can be expanded as built-in detector for HPLC-devices.

$>$ The proposed cell is perfect for the on-line monitoring of drug levels.

\section{Acknowledgements}

The authors would like to acknowledge financial support for this work, from the Deanship of Scientific Research (DSR), University of Tabuk, Tabuk, Saudi Arabia, under grant no. S-080-1436.

\section{References}

[1] Diphenhydramine. Wikipedia. https://en.wikipedia.org/wiki/Diphenhydramine

[2] Frag, E.Y.Z., Mohamed, G.G. and El-Sayed, W.G. (2011) Potentiometric Determination of Antihistaminic Diphenhydramine Hydrochloride in Pharmaceutical Preparations and Biological Fluids Using Screen-Printed Electrode. Biochemistry, 82, 79-86. http://dx.doi.org/10.1016/j.bioelechem.2011.05.006

[3] Dönmez, Ö.A., Aşçı, B., Bozdoğan, A. and Sungurs, S. (2011) Simultaneous Determination of Potassium Guaiacolsulfonate, Guaifenesin, Diphenhydramine HCl and Carbetapentane Citrate in Syrups by Using HPLC-DAD Coupled with Partial Least Squares Multivariate Calibration. Talanta, 83, 1601-1605. http://dx.doi.org/10.1016/j.talanta.2010.11.054

[4] Wang, C., Fan, G., Lin, M., Chen, Y., Zhao, W. and Wu, Y. (2007) Development and Validation of a Liquid Chromatography/Tandem Mass Spectrometry Assay for the Simultaneous Determination of d-Amphetamine and Diphenhydramine in Beagle Dog Plasma and Its Application to a Pharmacokinetic Study. Journal of Chromatography B, 854, 48-56. http://dx.doi.org/10.1016/j.jchromb.2007.03.038

[5] Ali, M.S., Ghori, M., Rafiuddin, S. and Khatri, A.R. (2007) A New Hydrophilic Interaction Liquid Chromatographic (HILIC) Procedure for the Simultaneous Determination of Pseudoephedrine Hydrochloride (PSH), Diphenhydramine Hydrochloride (DPH) and Dextromethorphan Hydrobromide (DXH) in Cough-Cold Formulations. Journal of Pharmaceutical and Biomedical Analysis, 43, 158-167. http://dx.doi.org/10.1016/j.jpba.2006.06.038

[6] Dong, Y., Chen, X., Chen, Y., Chen, X. and Hu, Z. (2005) Separation and Determination of Pseudoephedrine, Dextromethorphan, Diphenhydramine and Chlorpheniramine in Cold Medicines by Nonaqueous Capillary Electrophoresis. Journal of Pharmaceutical and Biomedical Analysis, 39, 285-289. http://dx.doi.org/10.1016/j.jpba.2005.02.032

[7] Gomez, M.R., Sombra, L., Olsina, R.A., Martínez, L.D. and Silva, M.F. (2005) Development and Validation of a Capillary Electrophoresis Method for the Determination of Codeine, Diphenhydramine, Ephedrine and Noscapine in Pharmaceuticals. Il Farmaco, 60, 85-90. http://dx.doi.org/10.1016/j.farmac.2004.11.002

[8] Barbas, C., Garcia, A., Saavedra, L. and Castro, M. (2000) Optimization and Validation of a Method for the Determination of Caffeine, 8-Chlorotheophylline and Diphenhydramine by Isocratic High-Performance Liquid Chromatography: Stress Test for Stability Evaluation. Journal of Chromatography A, 870, 97-103.

http://dx.doi.org/10.1016/S0021-9673(99)01186-3 
[9] Shoukry, A.F., Badawy, S.S. and Issa, Y.M. (1987) Diphenhydramine-Sensitive Membrane Electrodes Based on Poly(vinylchloride) Matrices and Their Use in Drug Analysis. Journal of Electroanalytical Chemistry and Interfacial Electrochemistry, 23, 29-36. http://dx.doi.org/10.1016/0022-0728(87)85003-9

[10] Okamoto, H., Uetake, A., Tamaya, R., Nakajima, T., Sagara, K. and Ito, Y. (2001) Simultaneous Determination of Ingredients in an Ointment by Hydrophobic Interaction Electrokinetic Chromatography. Journal of Chromatography A, 929, 133-141. http://dx.doi.org/10.1016/S0021-9673(01)01178-5

[11] Hodgkinson, L.C., Johnson, M.R., Leigh, S.J., Spencer, N. and Sutherland, I.O. (1979) Formation of Complexes between Aza Derivatives of Crown Ethers and Primary Alkylammonium Salts. Part 4. Diaza-18-Crown-6 Derivatives. Journal of the Chemical Society, Perkin Transactions I, 1979, 2193-2202. http://dx.doi.org/10.1039/p19790002193

[12] Zareh, M.M. (2010) Compact Cell for the Selective Determination of Ascorbic Acid. Sensor Letters, 8, 1-8. http://dx.doi.org/10.1166/sl.2010.1321

[13] Guilbault, G., Drust, R., Frant, M., Freiser, H., Hansen, H., Light, T., Pongor, E., Rechnitz, G., Rice, N., Rhom, T., Simon, W. and Thomas, J. (1976) Recommendation for Nomenclature of Ion-Selective Electrodes. Pure and Applied Chemistry, 48, 127-132.

[14] Zareh, M. (2008) Relative Selectivity Concept of Atropine Selective Electrodes. Analytical Sciences, 24, 889-894. http://dx.doi.org/10.2116/analsci.24.889 